\title{
United States of America
}

\section{"Mission Product Holdings"}

\section{Decision of the Supreme Court}

20 May 2019 - Case No. 17-1657

Mission Product Holdings, Inc. v. Tempnology, LLC, NKA Old Cold LLC

Bankruptcy Code, § 365

(C) Max Planck Institute for Innovation and Competition, Munich 2019

Keywords Trademarks - Bankruptcy $\cdot$ Rejection as contract rescission vs rejection as contract breach - Debtor's rejection of a licencing contract - Transfer of rights

1. Under $\S 365$, a debtor's rejection of an executory contract in bankruptcy has the same effect as a breach outside bankruptcy. Such an act cannot rescind rights that the contract previously granted.

2. The debtor-licensor's rejection of that contract does not deprive the licensee of its rights to use the trademark. A rejection breaches a contract but does not rescind it and that means all the rights that would ordinarily survive a contract breach remain in place.

a. $\$ 365(\mathrm{~g})$ provides that rejection "constitutes a breach of [an executory] contract". "Breach" is neither a defined nor a specialized bankruptcy term - it means in the Code what it means in contract law outside bankruptcy.

b. Outside bankruptcy, a licensor's breach cannot revoke continuing rights given to a counterparty under a contract (assuming no special contract term or state law). Because rejection "constitutes a breach," the same result must follow from rejection in bankruptcy. In preserving a counterparty's rights, $\S 365$ reflects the general bankruptcy rule that the estate cannot possess anything more than the debtor did outside bankruptcy. And conversely, allowing rejection to rescind a counterparty's rights would circumvent the Code's stringent limits on "avoidance" actions - the exceptional cases in which debtors may unwind prebankruptcy transfers that undermine the bankruptcy process.

Publisher's Note Springer Nature remains neutral with regard to jurisdictional claims in published maps and institutional affiliations.

Available at http://www.supremecourt.gov. 